shall ensure its completion, the present meeting of the permanent committee has a most practical and important duty before it. But it has still further matters of interest and importance to deal with.

First, as regards the chart and catalogue, it must be remembered that to a great extent the sixteen observatories have been working independently, and it is impossible that, in existing circumstances, these results can be entirely homogeneous.

For example, at some observatories the diameters of the star-discs have been measured; at others, the magnitudes have been estimated by comparison with sets of photographed images assumed to represent stars of known magnitude. It will be the business of the "Magnitudes Committee" to devise effective means for reducing these measures of diameter and miscellaneous estimates to a uniform and absolute system of magnitudes. Another committee will deal with the systematic errors which have been found to exist in the coordinates of star-images measured in certain series of plates. In some cases these errors depend on the magnitude of the star, in others on its distance and position angle from the centre ot the plate. The optical committee will have to trace, so far as possible, the origin of these errors, and devise means for eliminating their effects from the final results.

The coordinates of the star-images measured on the plates are of no value for the purposes of fundamental astronomy unless the system of the coordinates of each plate is referred to a number of stars the absolute positions of which on the sphere are known. In the case of some of the zones the places of the reference stars depend on meridian observations, few in number and made a considerable number of years ago; in other cases they depend on recent but only locally observed zones. It is essential that not only should adequate provision be made for proper meridian observation of the zones, but also for their coordination to a common system on the plan so far carried out by Dr. Kastner at Bonn. The arrangement of this part of the work will rest with the fundamental stars committee.

At the last meeting of the permanent committee in 1900 , a good deal of time was given to consideration of the steps to be taken for the observation of the then recently discovered planet Eros, at its opposition at the end of I9oo. The bureau of the committee has published a large number of the observations of Eros that were secured at the opposition of 1900 , as well as the results of meridian and photographic observations of the comparison stars, and an accurate ephemeris of the planet for that opposition. The unique characteristics of the orbit of Eros present conditions which are exceptionally favourable for researches of extraordinary astronomical interest and importance, viz. for the trigonometrical determination of the solar parallax and mass of the moon, and for the dynamical determination of the mass of the earth by the perturbations which it produces in the motion of Eros. In I 900 Eros approached the earth within one-third of the earth's mean distance from the sun, but at the opposition of I93 I it will approach the earth within half that distance, viz. within one-sixth part of the earth's mean distance from the sun. It is not, even now, too soon to begin preparation for this unique opportunity, and accordingly an Eros committee will be appointed for the following purposes:-

(a) $\mathrm{T} J$ receive reports on the actual state of the reducductions of the past observations of Eros, and to prepare a report upon them.

(b) To take steps for the preparation of an approximate ephemeris of Eros at the opposition of I93 I of sufficient accuracy to permit the selection of the most suitable comparison stars.

(c) To discuss the best methods of observing the opposition in question, especially with a view to avoid systematic error in the final results.

(d) To discuss the basis of the choice of comparison stars, and how to ensure their proper observation.

(e) To devise means for the regular observation of Eros from this time forward in order to perfect the ephemeris that will be finally employed in the definitive reduction of the observations of I93I, that is to say, for the direct determination of the solar parallax and mass of the moon, and also for the ultimate determination of the mass of the earth by means of the perturbations which it produces in the motion of Eros.

There can be no doubt that all these objects can only be attained by international cooperation, and that they furnish ample material for an interesting and important meeting. The following astronomers have accepted M. Baillaud's invitation on the part of the French Government to be present on the occasion : $\rightarrow$

Prof. Andoyer, Paris; Ch. André, Lyon; M. Angot, Paris; T. de Azcarate, San Fernando; O. Backlund, Pulkova; B. Baillaud, Paris; J. Baillaud, Paris; H. G. van de Sande Bakhuyzen, Leyden; Le Général Bassot, Nice; de la Baume Pluvinel, Paris; M. Bayet, Paris G. Bigourdan, Paris; G. Boccardi, Turin; Prince Roland Bonaparte; F. Boquet, Paris; H. Bourget, Marseilles; Sir W. H. M. Christie, Greenwich; W. E. Cooke, Perth; W. Australia; M. Cosserat, Toulouse; M. Deslandres, Meudon; A. Donner, Helsingfors; F. W. Dyson, Edinburgh; John Franklin-Adams, London; A. Gaillot, Paris; P. Gautier; Sir David Gill, London; M. Gonnessiat, Algiers; G. E. Hale, Mount Wilson; M. Hamy, Paris A. R. Hinks, Cambridge; S. S. Hough, Cape Town; Fernand Jacobs, Brussels; J. C. Kapteyn, Groningen; E. B. Knobel, London; M. Kromm, Bordeaux ; F. Küstner, Bonn; Le R. P. Laîs, Rome; I. Lagarde, Paris; A. Lebeuf, Besançon; G. Lecointe, Brussels; G. Leveau, Paris; M. Lumière, Lyon; Major P. A. MacMahon, London; J. Palisa, Vienna; C. D. Perrine, Mount Hamilton; L. Picart, Bordeaux; A. A. Rambaut, Oxford H. Renan, Paris; A. Ricco, Catania; J. Scheiner, Potsdam; M. Stéphan, Marseilles; E. Strömgren, Copenhagen ; H. H. Turner, Oxford; F. Valle, Tacubaya; M. Verschaffel, Abbadia; W. Zurhellen, Bonn.

\section{DR. ARTHUR GAMGEE, F.R.S.}

HIS numerous friends and fellow-workers in 1 science, both in this country and abroad, will hear with deep regret of the unexpected death of Dr. Arthur Gamgee, in Paris, on March 29. He was in his sixty-eighth year, and though not a young man was in full possession of an exception. ally endowed intellect which was ever urging him on in the path of research. Throughout a somewhat unsettled life his enthusiasm for research never waned from the time of his early student days, when he followed his natural leanings towards original physiological work, to which his exact knowledge of physics and chemistry was to be applied with a success that gained for him a wide and well-deserved reputation.

To many of the younger physiologists Dr. Gamgee was personally unknown. He was born in $184 \mathrm{I}$, in Edinburgh, a younger son of Joseph Gamgee, a distinguished veterinary surgeon and pathologist, whose work, particularly that on rinderpest, was well known in England and on the Continent. An elder brother, Joseph Sampson Gamgee, long connected with the general hospital in Birmingham, was a man of great mental gifts and remarkable personality, who made a name for himself in his profession, and will be remembered for the introduction of improved methods in the treatment of wounds 
in the pre-antiseptic days of surgery. Educated at University College School, Arthur Gamgee subsequently entered Edinburgh University, and came under the influence of John Goodsir and Christison, for both of whom he retained a warm affection throughout his life. After taking his medical degree in 1862 , the subject of his thesis, for which he was awarded a gold medal, being "An Inquiry into the Physiology and Pathology of Fœtal Nutrition," he became assistant to Maclagan, who was at that time professor of medical jurisprudence. Ten years later, after the publication of several physiological papers, among which the most important are those on the action of nitrites on hæmoglobin, on the development of heat in the process of arterialisation of the blood, which Mario Camis has only recently shown to be an exothermic reaction (Mem. Real. Acc. del Torino, 1908, 58, pp. I4 I-69), and, with J. Dewar, on the constitution of cystine-urinary calculi being at that time the only known source of this amino-acid, Gamgee was elected a Fellow of the Royal Society. He was at that time thirty-one years of age. In 1873 he became the first Brackenbury professor of physiology in Owens College, Manchester, where he founded the school in this subject, and as Dean of the medical school actively assisted in the transformation of the college into the Victoria University. His work in this direction seems to have been most unaccountably ignored, for his name is not even mentioned in a recently published history of the development of the university. From 1882 to 1885 he was Fullerian professor of physiology in the Royal Institution. A few years after leaving Manchester in 1885 Gamgee was elected assistant physician at St. George's Hospital, where he lectured on pharmacology and materia medica, and then, having decided to reside abroad, he practised as a consulting physician in Switzerland at Lausanne, and for several years at Montreux. During this time he was also actively engaged in research, and on his return to England in 1904 he continued his original work in Cambridge and in the physiological laboratory of the University of London, where, indeed, he was at work on the morning of the day of his departure for Paris. On two occasions, in 1902 and 1903 , he was invited to America, and his first visit was undertaken with the view of reporting upon the present state of our knowledge of nutrition, a subject which was being elaborately investigated by Chittenden, Atwater, and Benedict. From the Universities of Edinburgh and Victoria he received the honorary degrees of LL.D. and D.Sc., and during the last few months of his life was engaged in furthering the success of the International Congress of Applied Chemistry, which meets on May 26; of this he was vice-president of the physiological chemistry section. The council of the Royal Society chose him to represent the society at the celebration of Albrecht v. Haller's bicentenary at Berne last year.

The twelve years during which Dr. Gamgee worked in Manchester were in some respects the period of his greatest activity. Owens College was the foremost scientific institution in this country at that time, which was one of stress and strain for all who had the real interests of scientific work at heart. The paramount influence of Owens College in the 'sixties as a centre of scientific thought is hardly realised to-day, when the struggle from which an entirely new type of education was to be evolved is over, indeed is almost forgotten. The names of Sir Henry Roscoe, Balfour Stewart, Stanley Jevons, Boyd Dawkins, and Julius Dreschfield occur to us, among others, whom Gamgee found as his colleagues and friends, and he will always be associated with them as aiding in making the college the most conspicuous school of scientific research in the country.

The science of physiology, which has actually arisen and developed in this country within the last three decades, and become a school which easily ranks with any on the Continent or in America, owes much to its real founders, Michael Foster, Burdon Sanderson, and Arthur Gamgee, who were all well acquainted with the work of Claude Bernard, Car1 Ludwig, Du Bois Reymond, Helmholtz, and Kühne, and had recognised that only by an application of the experimental method to physiology, which was a subject that must be studied in adequately equipped laboratories, was there any probability of bringing this subject into line with other experimental sciences. In the development of this movement Arthur Gamgee took his share, and brought an acute intellect and a highly trained knowledge of chemical and physical methods to bear on the study of physiology. Apart from the original work which was done under his direction, the publication of the first volume of the "Text-book of the Physiological Chemistry of the Animal Body, including an Account of the Chemistry of Pathological Processes," marks an epoch in English physiology. This volume was dedicated to Christison. It at once established Gamgee's reputation, and even to-day remains one of the most accurate and valuable works in medical literature. The subject is treated from the biological rather than from the purely chemical point of view; it involved a vast amount of experimental work, and the book was what the author claimed it to be, an original work, and not a compilation of facts obtained by the evisceration of pre-existing treatises on physiological chemistry. The book will long remain a lasting credit to British physiology. Thirteen years later a second volume, which dealt with the chemistry of digestion, appeared, and, like its predecessor, this gave a complete survey of what was known at that time on the subject; that portion of the work which treated of the bile, jaundice, and the formation of gall-stones was of particular excellence. His address in $\mathrm{I} 882$, when as president of the Biological Section of the British Association it fell to his lot to express the loss which science had suffered by the deaths of Darwin and F. M. Balfour, was an historical account of the growth of our knowledge on the process of secretion. This address may well be studied by those who wish to grasp clearly the literary and scientific qualities of Gamgee's mind.

The application of physical and chemical methods to physiology was well seen in Gamgee's work. In the Croonian lecture before the Royal Society in 1904 he gave a full account of his life-long researches on hæemoglobin-the dextro-rotatory properties of this pigment, its absorption bands in the violet and ultra-violet portions of the spectrum, the para-magnetic property of hæmin and hæmatin, together with the demonstration that hæmoglobin falls as a coloured cloud in the colloidal state through a clear supernatant liquid in the anodic compartment of an electrolytic cell. These additions to knowledge we owe entirely to Gamgee. In later years his attention was devoted to the solution of a problem which had occupied his mind from the early days when he worked in Tait's laboratory, and in a paper published in the Philosophical Transactions for 1908 he showed for the first time how, by the employment of special thermoelectric junctions, improved thermostats, and the photographic recorder or the string recorder devised by Horace Darwin, a continuous or quasi-continuous registration of the diurnal curve of the fluctuations in the body temperature of animals

No. 2059, vol. 80] 
could be obtained. He completely solved this problem, and believed that this method was destined to prove an indispensable aid to clinical diagnosis. In this we do not think he was mistaken, though the technical difficulties in carrying out the method are considerable.

Dr. Gamgee, as is well known, was a man of the most affectionate disposition, enthusiastic in his work, a good linguist, a fluent speaker, and an excellent classical scholar. The simplicity of his mind and his single-heartedness of purpose endeared him to a wide circle of friends by whom he will be sincerely mourned; for those even nearer and dearer to him, his wife and children, his loss is great and irreparable.

G. A. B.

\section{NOTES.}

Prof. H. G. VAN DE SANde BakhuYzen has retired from the directorship of the Leyden Observatory. His place as professor of theoretical astronomy in the University is to be taken by Dr. W. de Sitter, of the Groningen Astronomical Laboratory, whilst Mr. E. F. van de Sande Bakhuyzen is to succeed him as professor of general astronomy and director of the observatory.

Prof J. Bauschinger has been appointed to succeed Prof. E. Becker as professor of astronomy and director of the university observatory at Strassburg, and Prof. Becker asks that all communications for him should now be addressed to Freiburg i. B., Reichsgrafenstrasse, 17.

With regard to the expedition for the exploration of the Charles Louis Mountains in New Guinea, announced in our issue of March Ir, we are asked to state, on behalf of the subscribers, that this expedition is being sent out under the auspices of the British Ornithologists' Union in commemoration of its jubilee, held last December, and described in Nature of December 24 (vol. Ixxix., p. 238). It was then decided that this expedition should be known as "The British Ornithologists' Union Jubilee Exploration of the Charles Louis Mountains."

Arrangements have been made for a visit by Count Zeppelin in his airship to the International Aëronautical Exhibition to be opened at Frankfort in July next. The airship will be accommodated during the exhibition in one of the large halls now being built in the grounds, and ascents with it will be made.

We learn from the Times that a wonderfully vivid mirage was witnessed from Grimsby on April 8 in the evening. The Humber is six miles wide there, and beyond is three miles of land. This appeared to be lifted high into the air and reversed, the trees inland having the appearance of growing upside down. The Spurn Lighthouse, reversed, was seen four miles from its position, and below the reflection of the land was the North Sea, on which were large steamers, with masts and funnels downwards, passing to and fro.

The Health Congress, Leeds, I909, organised by the City and the University of Leeds, with the cooperation of the Royal Sanitary Institute and the Royal Institute of Public Health, will be held on July $17-24$. The president is Colonel T. W. Harding, J.P., D.L., and the general secretaries are Dr. Spottiswoode Cameron and Mr. Robert E. Fox, the medical officer of health and town clerk respectively of Leeds. A programme of the preliminary arrangements is published in the Journal of the Royal Sanitary Institute for April (xxx., No. 3).

ONE of the special features of the great Missionary Exhibition, entitled "Africa and the East," which will be held at the Royal Agricultural Hall from June 8 to July 3 , under the auspices of the Church Missionary Society, will be a special exhibit of outfit suitable for missionaries and travellers, which will be shown in a special outfit section. One of the special features of this section will be an exhibition of the various methods of protection from mosquitoes and other insects, which play an important part in the spread of many tropical diseases. The organiser of the section is Dr. C. F. Harford, principal of Livingstone College, Leyton, E.

To encourage enterprise and experiment in British aviation, the Daily Mail offers a prize of 1000 . to the aëroplanist who, within twelve months of April 7, flies a distance of one mile either in a circuit or from a given point to another and returns to the starting point without touching the ground. The other conditions of the award are :-(I) that the motor, planes, propellers, and all other parts be entirely of British manufacture; (2) that the inventor and the aerroplanist be British subjects, and by British subjects we naturally include those in British colonies; (3) the flight shall take place within the British Isles, and be approved by officials of the recognised aviation organisation. Other prizes offered by the Daily Mail are:-10,0ool. for a flight by a heavier-than-air machine from London to Manchester with not more than two stops to take in petrol. Offered in November, r906; and open to aëronauts of all nations. roool. for a flight across the Channel by a heavier-than-air machine before the end of 1909. Open to all nations.

Dr. William Jones, assistant curator of the Field Columbian Museum of Chicago, has been murdered by tribesmen in the Philippines about fifty miles south of Echague. He had gone to the islands in 1906 on a four years' expedition to study the life of the Ilingots. Dr. Jones had Indian blood in his veins, and was born among the Sauk and Fox Indians of Oklahoma about thirtyfour years ago. $\mathrm{He}$ was educated at the Indian school at Hampton, at Andover Academy, and at Harvard, where he had a distinguished career. He took a post-graduate course at Columbia University, and was then engaged by the Carnegie Institution at Washington on ethnological investigations. His success in unravelling many mysteries of Indian religions led to his appointment at Chicago. According to his chief, Prof. G. A. Dorsey, he was the most promising student of ethnology in America, and a similar opinion has been expressed by the head of the Federal Bureau of Ethnology. The day before the receipt of the cablegram announcing his death, Prof. Dorsey had heard by letter from Dr. Jones of his intention to leave the friendly tribe with whom he had been living in order to pursue his researches in a remote section of the country, which would necessitate his passing through a hostile territory.

THE geological department of the British Museum (Natural History) has received from the National Museum of Natural History, Paris, a plaster cast of the finest skull and mandible of the long-chinned mastodont, Tetrabelodon angustidens, from the Middle Miocene of Sansan (Gers), France. The specimen has just been mounted for exhibition with Dr. Andrews's well-known models of the skull and mandible of Mœritherium and Palæomastodon from the Upper Eocene of the Fayum, Egypt. These three specimens are arranged in series with the American Pleistocene Mastodon americanus, so that the principal stages in the evolution of the proboscidean head can now be studied in one view. They show very clearly the lengthening of the symphysis of the lower jaw, which 